\begin{tabular}{llllllllllll}
$\mathbf{S}$ & $\mathbf{P}$ & $\mathbf{R}$ & $\mathbf{A}$ & $\mathbf{W}$ & $\mathbf{O}$ & $\mathbf{Z}$ & $\mathbf{D}$ & $\mathbf{A}$ & $\mathbf{N}$ & $\mathbf{I}$ & $\mathbf{A}$ \\
\hline
\end{tabular}

STUDIA POLONIJNE

T. 39. LUBLIN 2018

\author{
JAROSŁAW WĄSOWICZ SDB \\ dyrektor Archiwum Salezjańskiego Inspektorii Pilskiej \\ e-mail:wonsal_@poczta.onet.pl
}

\title{
„MILION ZZA OCEANU”. AMERYKANIE POLSKIEGO POCHODZENIA W ARMII USA W CZASIE DRUGIEJ WOJNY ŚWIATOWEJ/ „A MILLION OVERSEAS”. AMERICANS OF POLISH DESCENT IN THE US ARMY DURING WORLD WAR II. WYSTAWA CZASOWA W MUZEUM II WOJNY ŚWIATOWEJ, Gdańsk, 6 lipca - 31 października 2018
}

DOI: http://dx.doi.org/10.18290/sp.2018.18

Zagadnienie służby Polaków w obcych formacjach wojskowych podczas II wojny światowej przez długie lata nie było obecne w polskiej historiografii. Działo się tak z różnych przyczyn. W większości przypadków decydowały te natury politycznej. Fakt, iż po 1945 roku znaleźliśmy się wśród państw kontrolowanych przez Związek Socjalistycznych Republik Radzieckich, determinował również kierunki badań naukowych. W historiografii PRL nie pojawiały się więc takie tematy, jak przymusowe wcielanie obywateli II Rzeczypospolitej (głównie Ślązaków i Kaszubów) do Wehrmachtu. Pamiętać też musimy, iż w niemieckich formacjach wojskowych służyli także Polacy lub osoby z polskim pochodzeniem zamieszkujący przed wojną tereny przynależące do Niemiec i jako posiadający obywatelstwo niemieckie, podlegali obowiązkowi służby wojskowej w tym samym zakresie, co inni obywatele III Rzeszy. Podobnie rzecz się miała odnośnie do Polaków, którzy zamieszkiwali na terenie Związku Radzieckiego. Do Armii Czerwonej byli też wcielani mieszkańcy Kresów II Rzeczypospolitej, zajętych przez Sowietów we wrześniu 1939 roku w ramach Paktu Ribbentrop-Mołotow. Polacy walczyli również w wojnach alianckich, zwłaszcza francuskich i brytyjskich. Odnajdziemy ich w także w szeregach US Army.

Początki badań nad zaangażowaniem Polaków i Amerykanów polskiego pochodzenia w czyn zbrojny armii amerykańskiej podczas II wojny światowej związane są nierozłącznie z osobą Mieczysława Haimana, wielkiego społecznika, działacza polonijnego w USA, twórcy Polskiego Muzeum w Chicago. Wiosną 1944 roku Heiman rozesłał na ten temat ankietę do 796 polskich parafii w USA i uzyskał odpowiedź aż z 538 placówek. Niestety, w 1946 roku badacz zmarł i wyniki jego pracy czekać musiały na ponowne odkrycie do czasów nam współczesnych. Okazało się, iż na podstawie zebranych w ankietach danych 
Mieczysław Haiman oszacował, że podczas wojny w US Army walczyło około miliona osób polskiego pochodzenia. Znakomita większość z nich chciała w ten sposób wesprzeć ojczyznę za oceanem walczącą o wolność.

Ustalenia emigracyjnego działacza amerykańskiej Polonii stały się głównym motywem sprawczym wystawy „Milion zza Oceanu”, przygotowanej staraniem Muzeum II Wojny Światowej i prezentowanej w Gdańsku w dniach 6 lipca - 31 października 2018, która opowiada historię osób polskiego pochodzenia i Polaków pełniących służbę w US Army w latach 1939-1945. Partnerem muzeum w realizacji tego przedsięwzięcia było Stowarzyszenie Historyczne Wielka Czerwona Jedynka, kultywujące historię 1. Dywizji Piechoty Armii USA. Kuratorami ekspozycji i zarazem autorami jej koncepcji byli: Bartłomiej Graba, Marek Zambrzycki oraz Andrzej Hoja i Piotr Langenfeld. Konsultantami naukowymi całego przedsięwzięcia byli natomiast prof. dr hab. Grzegorz Berendt oraz dr Karol Nawrocki. Należy wspomnieć, iż staraniem Muzeum II Wojny Światowej został wydany w atrakcyjnej szacie graficznej katalog wystawy. Dyrektor tej placówki, dr Karol Nawrocki, w słowie wstępnym do tej publikacji zaznaczył m.in.: „Amerykańscy żołnierze z polskimi korzeniami, których przypominamy w tym wydawnictwie, współtworzą piękną historię walki dobra ze złem. Kierowani niejednokrotnie odruchem serca byli gotowi poświęcić własne życie, aby wspierać wysiłki aliantów w walce $\mathrm{z}$ totalitarnymi systemami".

Przypomnijmy, że Stany Zjednoczone Ameryki Północnej zaangażowały się bezpośrednio w działania wojenne po ataku Japończyków na amerykańskie bazy floty i lotnictwa w Pearl Harbor na Hawajach, który miał miejsce 7 grudnia 1941 roku. W ciągu dwóch godzin nalotów japońska marynarka wojenna osiągnęła taktyczne zaskoczenie, zadając duży cios amerykańskim zasobom militarnym na Pacyfiku. Zginęło wówczas ponad 2300 amerykańskich żołnierzy. W tym gronie znajdujemy pierwsze ofiary US Army polskiego pochodzenia. W kolejnych dniach USA wypowiedziały wojnę Japonii, na co natychmiast zareagowali jej sojusznicy, III Rzesza i Królestwo Włoch, wypowiadając wojnę Amerykanom, a Kongres USA w odpowiedzi ogłosił stan wojny z oboma tymi krajami. Warto w tym miejscu przypomnieć, że na atak na USA odpowiedział także polski Rząd na Wychodźstwie. W dniu 11 grudnia prezydent Władysław Raczkiewicz ogłosił stan wojny Rzeczpospolitej Polskiej z Japonią. Jeszcze w tym samym roku w USA zmieniono ustawę o poborze, która w związku z przystąpieniem do wojny objęła mężczyzn w wieku 20-44 lat. Na arenę międzynarodowego konfliktu wkroczył wielki gracz z kilkunastoma milionami rekrutów, w tym milionem żołnierzy pochodzenia polskiego.

Ekspozycja upamiętnia ich czyn zbrojny, z drugiej jednak strony ukazuje losy konkretnych osób na tle wydarzeń historycznych związanych głównie z okresem II wojny światowej. Odnajdziemy na niej również informacje na temat udziału obywateli USA polskiego pochodzenia w walce o wolność Polski już w czasie I wojny światowej, głównie w „Błękitnej Armii” gen. Józefa Hallera, niezbędne - jak się wydaje - do zrozumienia ich zaangażowania w kolejnym światowym konflikcie zbrojnym. Znajdziemy także informacje o Polakach służących w US Army na terenie Europy już po zakończeniu wojny, chociażby w polskich jednostkach wartowniczych przy jednostkach amerykańskiej armii, których członkowie rekrutowali się m.in. z byłych robotników przymusowych czy też więźniów obozów koncentracyjnych. Opiekę duszpasterską nad nimi pełnili m.in. księża wyzwoleni 
z KL Dachau, którzy jako kapelani podjęli służbę w alianckich armiach i pełnili ją w wielu wypadkach aż do momentu powrotu do ojczyzny.

Wśród osób przywołanych na wystawie odnajdziemy postaci znane odbiorcy o przeciętnych zainteresowaniach historycznych. Na pewno należy do nich Leon Niemczyk (1923-2006), znany aktor, który po upadku Powstania Warszawskiego z niemieckiej niewoli przedarł się do US Army i podjął służbę w 444. Batalionie przeciwlotniczym 97. Dywizji Piechoty 3 Armii, dowodzonej przez gen. George'a Pattona - wielkiego przyjaciela Polski. Następnie Niemczyk służył w kompaniach wartowniczych. Innym znanym bohaterem, którego odnajdziemy na omawianej ekspozycji, jest gen. Witold Urbanowicz (1908-1996), uczestnik bitwy o Anglię i dowódca Dywizjonu 303. Walczył też jako pilot jednostek amerykańskich na froncie chińskim, zaś po wojnie był wieloletnim pracownikiem amerykańskiego przemysłu lotniczego.

Natomiast wśród mniej rozpoznawalnych bohaterów w gronie przeciętnych odbiorców można wymienić inne zaprezentowane na wystawie postaci, jak chociażby Francis Stanley „Gabby” Gabreski (1919-2002) - amerykański pilot polskiego pochodzenia, który zakończył II wojnę światową z trzecim miejscem na liście asów USA, pomimo tego, że część wojny spędził w niemieckiej niewoli w Stalagu Luft I w Barth. Po wyzwoleniu powrócił do USA i do końca zawodowej kariery pełnił ważne funkcje w amerykańskich siłach lotniczych. Podczas II wojny światowej w wojskach generała Pattona służył m.in. Albin Felix Irzyk (1917-2018), który był dowódcą 8. Batalionu czołgów 4. Dywizji Pancernej US Army. W latach 60. XX wieku, już jako generał, dowodził w wojnie wietnamskiej. Ciekawym przypadkiem jest postać Edwarda Slovika (1920-1945), który służył we Francji w 109. Pułku 28. Dywizji Piechoty. Został rozstrzelany za dezercję, jako pierwszy amerykański żołnierz od czasów wojny secesyjnej.

Podobnych ciekawostek z historii życia naszych rodaków walczących w szeregach US Army odnajdziemy na omawianej wystawie więcej. Całość jej narracji została ujęta w dziesięć bloków tematycznych, które odnajdziemy pod następującymi tytułami: „Ankieta Haimana”; „W cieniu doktryny Monroe'a”; „Echa wojny”; „Mobilizacja”; „Walka w powietrzu”; „Na szlaku bojowym”; „Okrucieństwo wojny”; „Strach i dezercja”; „Gdy nastał pokój”; „Po wojnie też jest życie”.

Całość przedsięwzięcia była prezentowana w sali wystaw czasowych muzeum. Autorkami koncepcji przestrzenno-graficznej były Monika Potarska oraz Natalia Gawryluk. Oprócz wspomnianych życiorysów żołnierzy, odnajdziemy na niej także oryginalne eksponaty, m.in. pamiątki po wspomnianym już Witoldzie Urbanowiczu, legendarnym dowódcy Dywizjonu 303. Na wystawie zaprezentowano np. wypożyczony z muzeum w Suwałkach medalik, który Urbanowicz otrzymał od matki. Ponadto w przestrzeni ekspozycji wykorzystano mundury różnych formacji US Army i jej wyposażenie. Szczególnym eksponatem był Willys MB symbol amerykańskiego zaangażowania w wysiłek II wojny światowej, który w związku z wystawą został pozyskany do zbiorów Muzeum II Wojny Światowej w Gdańsku. Poza armią USA był on masowo użytkowany przez wojska brytyjskie, kanadyjskie, australijskie, Polskie Siły Zbrojne na Zachodzie, a także armię sowiecką. Egzemplarz, w którego posiadanie weszła gdańska placówka, był pojazdem dowództwa kompanii F, 2. batalionu, 32. pułku artylerii, 1. dywizji piechoty USA i został wyprodukowany w lipcu 1944 roku. 
Wystawa „Milion zza Oceanu” cieszyła się sporym zainteresowaniem osób, które od pierwszych dni lipca do końca października odwiedziły Muzeum II Wojny Światowej. Dodać należy, że 12 lutego 2018 roku, staraniem dyrekcji muzeum, Konsulatu Generalnego RP w Nowym Jorku oraz Komitetu Obchodów Rocznicy Katastrofy Smoleńskiej i Ludobójstwa Katyńskiego, wystawa trafiła do amerykańskiej Polonii. Przy okazji jej otwarcia dyrektor gdańskiej placówki dr Karol Nawrocki zaprezentował przedstawicielom naszych rodaków zza oceanu projekt „Muzeum II Wojny Światowej w Gdańsku - szansa opowiedzenia światu polskiej historii", natomiast zastępca dyrektora ds. inwestycyjno-administracyjnych Julia Olechno przedstawiła prezentację „Wokół Westerplatte”.

Omawiana ekspozycja była najpierw prezentowana w budynku konsulatu w Nowym Jorku, następnie staraniem klubów „Gazety Polskiej” także w Bostonie i Filadelfii oraz Clark w stanie New Jersey. Natomiast w dniach 17-19 sierpnia 2018 roku mogli się z nią zapoznać uczestnicy uroczystych obchodów Dnia Żołnierza i Stulecia Czynu Zbrojnego Polonii Amerykańskiej i Kanadyjskiej, które miały miejsce w Narodowym Sanktuarium Matki Bożej Częstochowskiej w Doylestown w stanie Pensylwania. Zostały one zorganizowane przez II Okręg Stowarzyszenia Weteranów Armii Polskiej w Ameryce. Należy żywić nadzieję, że będą mogły w przyszłości zapoznać się z nią także inne środowiska polonijne.

\section{MARIA ANNA FURTAK}

doktorantka, Instytut Historii na WNH KUL

e-mail: furtakma@gmail.com

\section{SESJA PODSUMOWUJACA PROJEKT „PARAFIE I KOŚCIOLY POLSKIE W USA. INWENTARYZACJA ŹRÓDŁOWA I FOTOGRAFICZNA POLISH CATHEDRALS" (CZEŚŚC I) 1 grudnia 2017 KUL i 8 grudnia 2017 UKSW}

DOI: http://dx.doi.org/10.18290/sp.2018.19

W dniach 1 grudnia na Katolickim Uniwersytecie Lubelskim Jana Pawła II oraz 8 grudnia na Uniwersytecie Kardynała Stefana Wyszyńskiego w Warszawie odbyły się sesje naukowe podsumowujące pierwszy etap projektu „Parafie i kościoły polskie w USA. Inwentaryzacja źródłowa i fotograficzna Polish Cathedrals", dofinansowanego przez Ministerstwo Kultury i Dziedzictwa Narodowego. Przedmiotem prac, jakie Ośrodek Badań nad Polonią i Duszpasterstwem Polonijnym KUL podejmuje w ramach projektu we współpracy z Instytutem Historii Sztuki UKSW, są kościoły polskie na terenie Stanów Zjednoczonych, zaliczane do kategorii tzw. Polish Cathedrals: ich historia, architektura oraz wyposażenie wnętrz. Pierwszy etap dotyczył 21 obiektów tego typu na terenie Chicago oraz jego przedmieściach.

Sesję 1 grudnia 2017 otworzył prodziekan Wydziału Nauk Humanistycznych KUL, prof. Dariusz Skórczewski, nad porządkiem obrad czuwał ks. dr Sławomir Zych. 